\title{
Addition of Heteroatom Radicals to endo-Glycals ${ }^{\dagger}$
}

\author{
Torsten Linker (1)
}

Department of Chemistry, University of Potsdam, Karl-Liebknecht-Str. 24-25, 14476 Golm, Germany; linker@uni-potsdam.de; Tel.: +493319775212

+ Dedicated to Bernd Giese on the occasion of his 80th birthday and his pioneering work on radicals in carbohydrate chemistry.

Received: 6 February 2020; Accepted: 18 February 2020; Published: 20 February 2020

\begin{abstract}
Radical reactions have found many applications in carbohydrate chemistry, especially in the construction of carbon-carbon bonds. The formation of carbon-heteroatom bonds has been less intensively studied. This mini-review will summarize the efforts to add heteroatom radicals to unsaturated carbohydrates like endo-glycals. Starting from early examples, developed more than 50 years ago, the importance of such reactions for carbohydrate chemistry and recent applications will be discussed. After a short introduction, the mini-review is divided in sub-chapters according to the heteroatoms halogen, nitrogen, phosphorus, and sulfur. The mechanisms of radical generation by chemical or photochemical processes and the subsequent reactions of the radicals at the 1-position will be discussed. This mini-review cannot cover all aspects of heteroatom-centered radicals in carbohydrate chemistry, but should provide an overview of the various strategies and future perspectives.
\end{abstract}

Keywords: radicals; carbohydrates; heteroatoms; synthesis

\section{Introduction}

Radical reactions of carbohydrates are important for chemistry, biology, and medicine. For example, free radicals are involved in several biosynthetic pathways or are used for cancer-treatment [1-4]. On the other hand, radiation can cause DNA strand break by $\mathrm{H}$ atom abstraction and radical generation at the sugar backbone [5-7]. Bernd Giese's group proved that radical cations are involved in the mechanism [8] and investigated how the positive charge is transferred through the DNA [9]. For synthetic applications, Bernd Giese's group also made carbohydrate radicals available for the formation of carbon-carbon bonds under mild conditions [10]. Due to steric interactions, carbohydrates provide high stereoselectivities [11,12], and the importance of such reactions has been reviewed many times [13-18]. Furthermore, under appropriate conditions, 2-deoxy sugars can be synthesized from bromo sugars in only one step [19].

To develop efficient radical reactions, it is important to understand the reactivities of the corresponding radicals $[12,20,21]$. Thus, such reactive species can have a nucleophilic or an electrophilic character [22], which controls their addition to alkenes. Applied to the anomeric center of carbohydrates, the radicals 1 exhibit a nucleophilic character due to the adjacent oxygen atom, and add preferentially to electron poor double bonds with electron withdrawing (EWG) and nondonating (EDG) groups (Scheme 1a). If the carbohydrate is used as radical acceptor, unsaturated carbohydrates like endo-glycals 2 become attractive substrates, which can be easily synthesized on a large scale [23]. However, once the double bond becomes electron rich the reaction proceeds only with electrophilic radicals (Scheme 1b). 
(a)
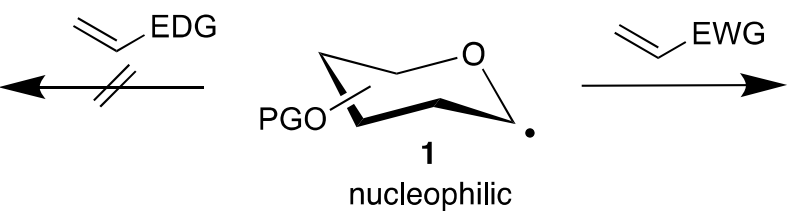

(b)
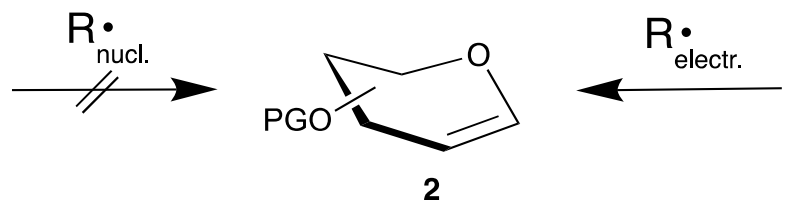

Scheme 1. Examples for radical reactions in carbohydrate chemistry: (a) starting from a carbohydrate radical 1 and (b) radical additions to glycals 2 .

During the last 25 years, we developed C-C bond formations by the addition of electrophilic radicals, mainly derived from malonates, to glycals 2 with various further synthetic transformations [24-27]. However, the addition of heteroatom radicals to glycals is very attractive as well, since such radicals exhibit the required electrophilic character [22,28]. On the other hand, heteroatom radicals are prone to undergo $\mathrm{H}$ atom abstraction, which is problematic in carbohydrate chemistry with various functional groups. Thus, although alkoxyl radicals [29] can be generated from carbohydrates and undergo fast fragmentations [30,31], of the way in which such radicals can be added to glycals is unknown. Since halogen atoms, nitrogen-, phosphorus-, and sulfur-centered radicals are less prone to undergo $\mathrm{H}$ atom abstraction, this mini-review will focus on the addition of such radicals to endo-glycals.

\section{Addition of Halogen Atoms}

The halogenation of endo-glycals 2 is one of the oldest transformations of such unsaturated carbohydrates, already described by Lemieux in 1965 [32]. Thus, tri-O-acetyl-D-glucal (2a) or the corresponding isomer tri-O-acetyl-D-galactal $(\mathbf{2 b})$ reacted with chlorine or bromine in high yields to the main products $\mathbf{3} \mathbf{a}$ and $\mathbf{3 b}$ (Scheme 2).
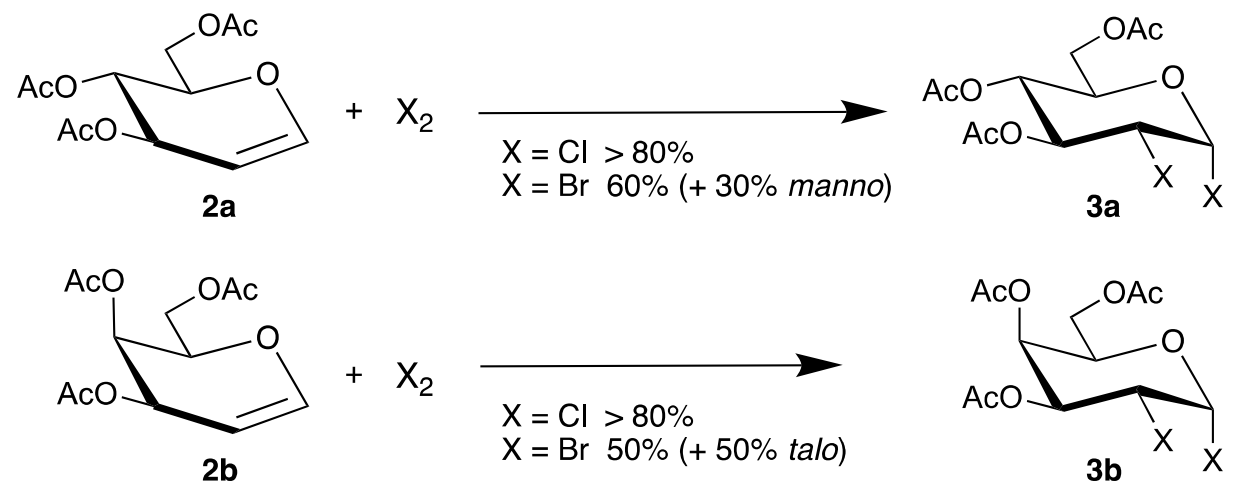

Scheme 2. Halogenation of glycals $2 \mathbf{a}$ and $\mathbf{2 b}$.

Although the authors proposed an ionic pathway via halonium ions, the 1,2-cis-configurations might be explained by homolysis of the labile halogen bonds and addition of the resulting electrophilic radicals. To distinguish between a radical or an ionic pathway, halogen azides are attractive precursors because they easily undergo homolysis and are used in regio- and stereoselective syntheses [33]. Thus, reaction of tri-O-acetyl-D-glucal (2a) with chlorine azide afforded regioisomers 4 and 5, depending on the reaction conditions (Scheme 3) [34]. 


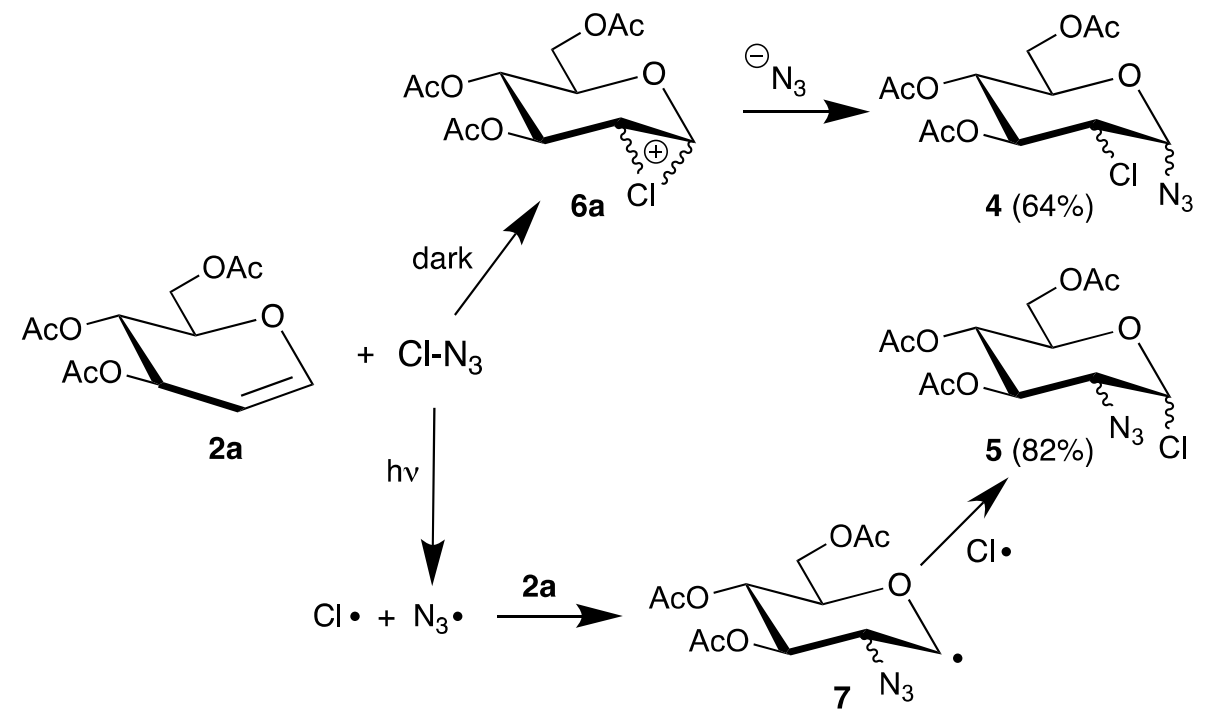

Scheme 3. Reaction of tri-O-acetyl-D-glucal (2a) with chlorine azide.

In the dark, 2-chloro-2-deoxy sugars 4 were isolated as main products, whereas irradiation gave the 2-azido-2-deoxy isomer 5 . Such different regioselectivities were explained by an ionic pathway via chloronium ions $6 \mathbf{a}$ in the dark and a radical mechanism during irradiation via radical 7 . However, it was not possible to add the generated chlorine atom to the glucal, because the azide radical is more reactive (see Section 3).

More recently, Vankar developed a reagent system based on oxalyl chloride and silver nitrate to activate the carbon-chlorine bond [35]. An intermediate 8 was proposed, which cleaves into nitrate and carbon monoxide and transfers chlorine to the double bond of tri-O-acetyl-D-galactal (2b). The chloronium ion $\mathbf{6 b}$ is subsequently trapped by the solvent acetonitrile/water to afford the 2-chloro-2-deoxy sugar 9 in high yield (Scheme 4).

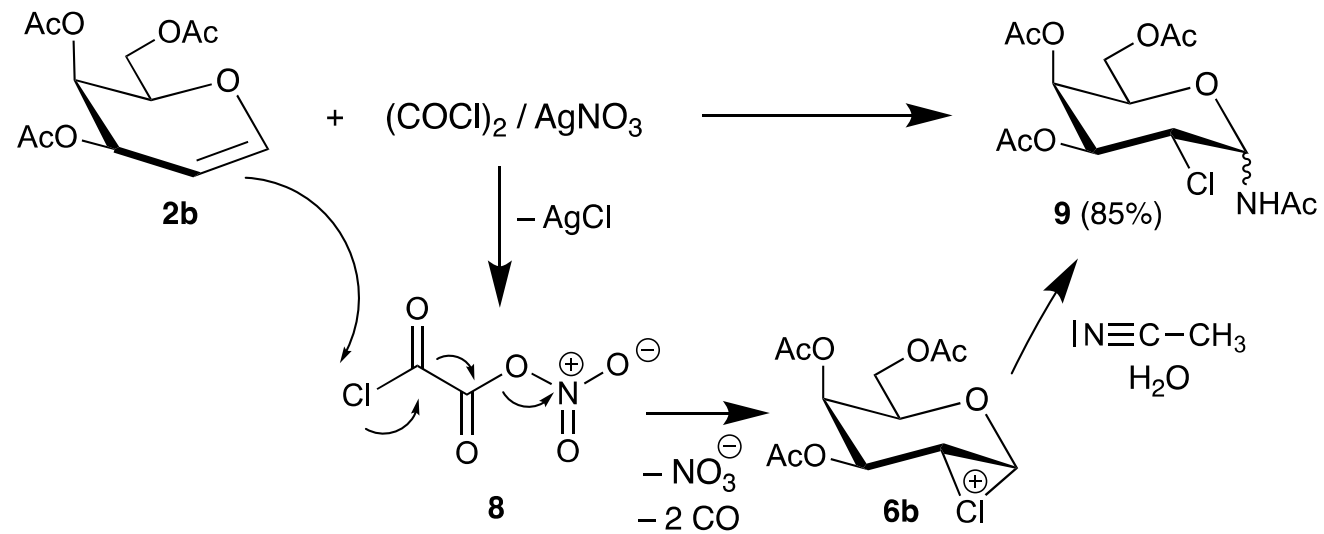

Scheme 4. Reaction of tri-O-acetyl-D-galactal (2b) with oxalyl choride/silver nitrate.

Compared to 2-chloro derivatives, the corresponding iodides are even more attractive because the carbon-iodine bond can be easily reduced to 2-deoxy sugars, important building blocks for carbohydrate chemistry. Thus, various strategies have been developed by oxidation of iodides by hypervalent iodine(III) [36,37] or sodium periodate [38] in the presence of endo-glycals 2, affording 2-iodo-2-deoxy sugars $\mathbf{1 0}$ in very good yields (Scheme 5). The mechanism proceeds by oxidation of iodide to iodine in the first step, formation of an iodonium ion similar to intermediate 6a (Scheme 3), and trapping of the 1-position with the carboxylate with high 1,2-trans selectivity. In summary, halogen atoms can be easily 
introduced at the 2-position of glycals. However, the reactions proceed mainly by ionic pathways, and irradiation of halogen azides results in the formation of $\mathrm{C}-\mathrm{N}$ bonds in the 2-position.

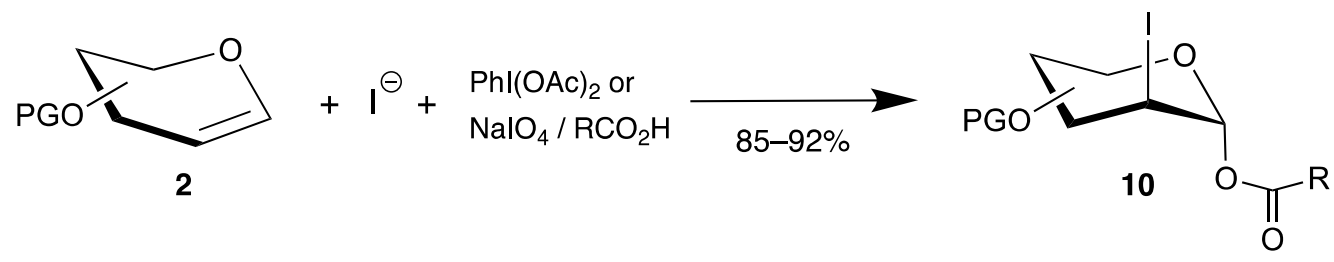

Scheme 5. Synthesis of 2-iodo-2-deoxy sugars 10 from endo-glycals 2.

\section{Addition of Nitrogen-Centered Radicals}

In contrast to halogenations (chapter 2), the oxidative addition of azides to endo-glycals clearly proceeds by a radical pathway. The azidohalogenation was one example (Scheme 3); however, it is more attractive to generate the radicals by electron transfer. Cerium(Iv) ammonium nitrate (CAN) is a very versatile single-electron oxidant, which can oxidize anions efficiently and has found many applications in organic synthesis [39]. We used this reagent for the generation of malonyl radicals and investigated the mechanism of their reactions with glycals $\mathbf{2}[25,26,40]$. The pioneer Lemieux described the first application of azide oxidation in carbohydrate chemistry by addition of sodium azide to tri-O-acetyl-D-galactal (2b) in the presence of CAN (Scheme 6) [41].

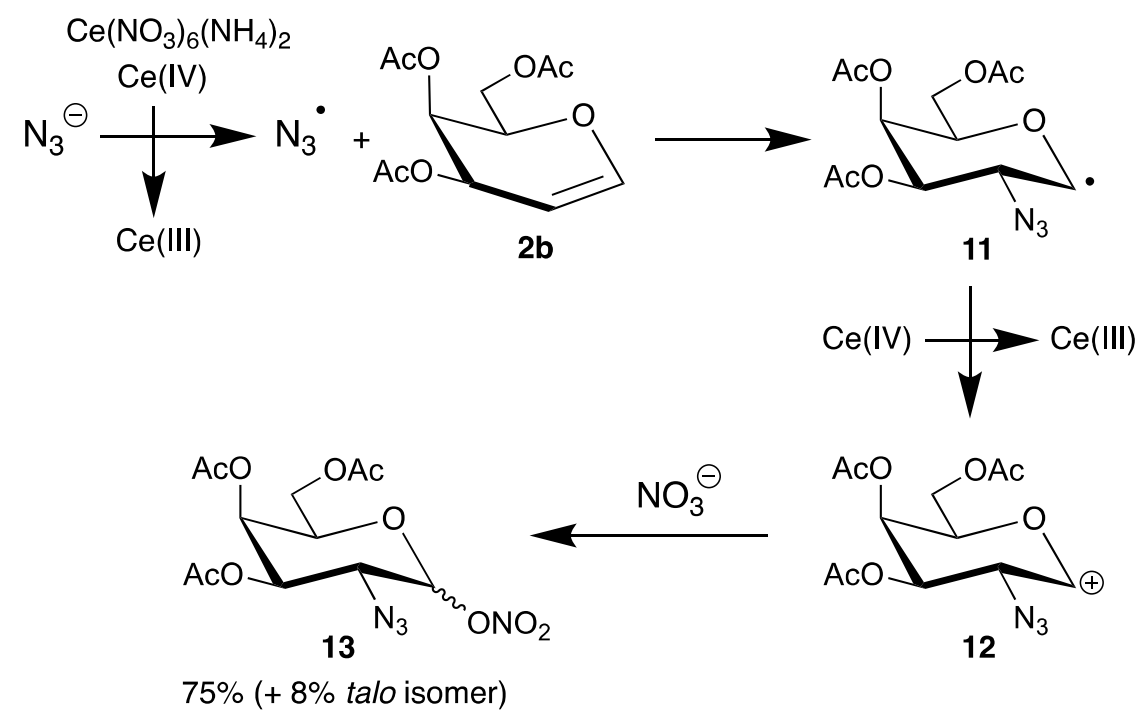

Scheme 6. Addition of sodium azide to tri-O-acetyl-D-galactal (2b) in the presence of cerium(Iv) ammonium nitrate (CAN).

In the first step, CAN oxidizes the azide anion to the corresponding radical, which has electrophilic character and adds to the double bond exclusively at the 2-position. The preferential formation of the equatorial product (only $8 \%$ of the talo isomer is formed as well) can be explained by the steric demands of the substituents in the 3- and 4-position. The resulting C-1 radical 11 is further oxidized by CAN to the carbenium ion 12, which is finally trapped by the nitrate ligand from both faces to afford the 2-azido-2-deoxy sugar 13 in 75\% yield. Thus, this addition is not a typical radical chain-reaction [13] because more than two equivalents of $\mathrm{CAN}$ are required.

The azidonitration of glycals was later extended to tri-O-acetyl-D-glucal (2a), but with lower stereoselectivity because not all substituents shield the same face. Furthermore, Paulsen [42] and Schmidt [43] found with this glucal 2a different selectivities depending on the reaction conditions and temperature. However, up to now the azidonitration of glycals has been the best method to 
synthesize 2-amino sugars by simple reduction of the azide group, and has found many applications in carbohydrate chemistry, like in a very recent synthesis of a bisphosphorylated trisaccharide [44].

However, a disadvantage of the azidonitration of glycals is the lability of the nitrate group at the anomeric center, which can be easily hydrolyzed. Although it is possible to use glycosyl nitrates directly for glycosidations [45], they usually have to be transformed into suitable glycosyl donors. To overcome this problem, an interesting azidophenylselenylation has been developed [46-48]. Now, sodium azide is oxidized by (diacetoxyiodo)benzene to the corresponding radical, which adds regioselectively to glycals like tri-O-acetyl-D-galactal (2b) (Scheme 7). In the presence of diphenyldiselenide, the C-1 radical is trapped to afford directly selenoglycoside $\mathbf{1 4}$ in high yield and steroeselectivity [47].
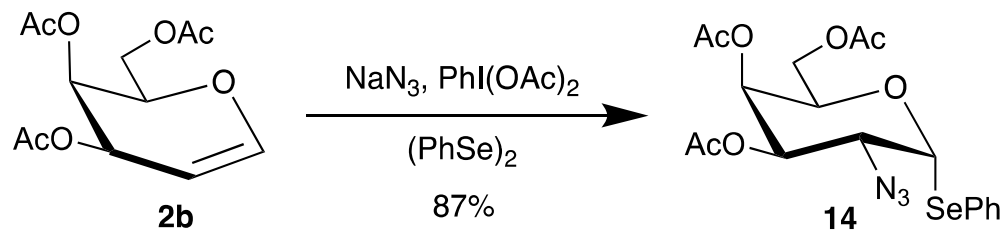

Scheme 7. Azidophenylselenylation of tri-O-acetyl-D-galactal (2b).

An interesting intramolecular version of a radical C-N bond formation was developed by Rojas (Scheme 8) [49] In the first step, azidoformate 2c reacts with $\mathrm{FeCl} 2$ under extrusion of nitrogen to intermediate 15, which can be discussed as a Fe-complexed nitrogen-centered radical. Addition to the double bond affords C-1 radical 16, which is trapped by chlorine to the labile complex 17; after work-up, tricycle 18 is formed in moderate yield.

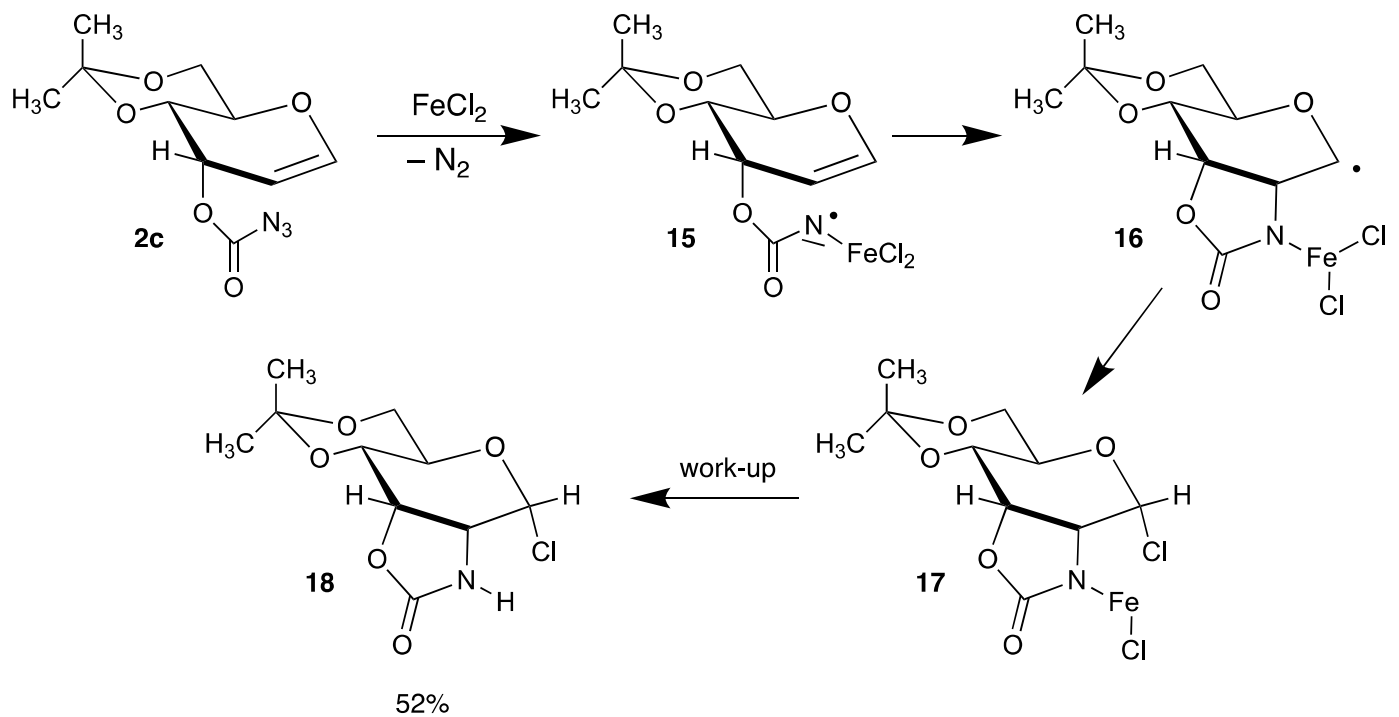

Scheme 8. Intramolecular addition of a nitrogen-centered radical 15.

A similar intermolecular addition of hydroxylamines as radical precursors to glycals was described recently as well [50] In summary, the formation of C-N bonds in the 2-position of carbohydrates can be easily accomplished by the addition of nitrogen-centered radicals to glycals. The best method is azidonitration in the presence of cerium(Iv) ammonium nitrate, or azidophenylselenylation, which has found many applications in carbohydrate chemistry.

\section{Addition of Phosphorus-Centered Radicals}

The reaction of phosphorus-centered radicals is well-established and has many synthetic applications, summarized in several reviews $[28,51,52]$. Because phosphorus can exist in different oxidation states, it is possible to generate phosphinyl, phosphinoyl, or phosphonyl radicals. 
Furthermore, the lability of the phosphorus-hydrogen bond allows for efficient chain-reactions with only catalytic amounts of radical initiator or under photochemical conditions. However, in contrast to nitrogen, only a few examples of the addition of phosphorus-centered radicals to glycals have been described in literature. Already in 1969, Inokawa demonstrated that diethyl thiophosphite reacts with unprotected glucal $\mathbf{2 d}$ under UV irradiation with a high-pressure mercury lamp to the 2-deoxy-2-phosphorus analogue 21 in high yield and stereoselectivity (Scheme 9) [53].

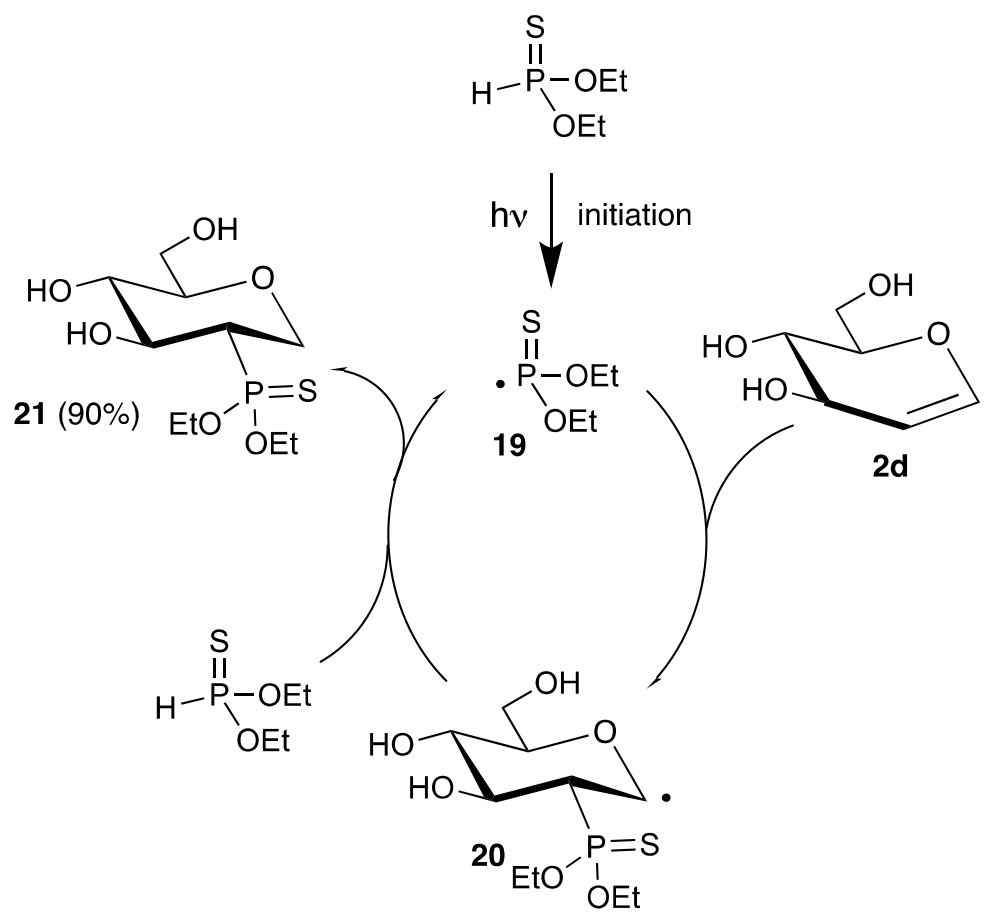

Scheme 9. Addition of diethyl thiophosphite to D-glucal (2d) under irradiation.

After the radical initiation step, the thiophosphonyl radical 19 adds regioselectively to the 2-position of the carbohydrate, due to its electrophilic character. The resulting C-1 radical 20 abstracts a hydrogen atom from diethyl thiophosphite, regenerating the phosphorus-centered radical 19, closing the chain.

A very similar approach with protected tri-O-acetyl-D-glucal (2a) was published more recently (Scheme 10) [54]. This time, the radical chain was initiated by triethylborane/air, which generates ethyl radicals, and the additions of diethyl thiophosphite and diethyl phosphite were realized. However, the reactions afforded products $\mathbf{2 2} \mathbf{a}$ and $\mathbf{2 2 b}$ in somewhat lower yields compared to the photochemical process.

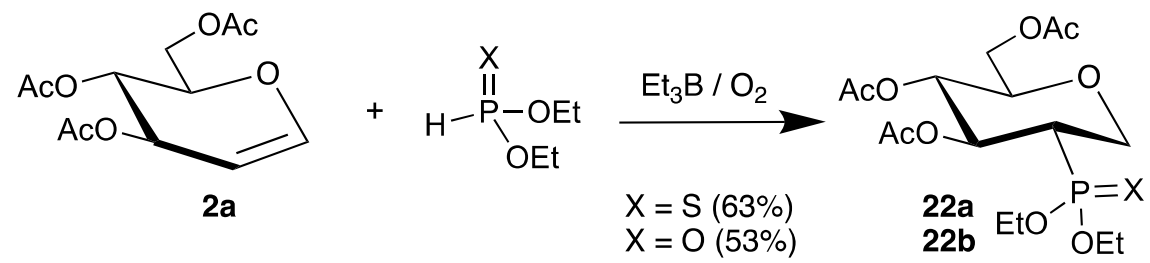

Scheme 10. Addition of diethyl phosphites to tri-O-acetyl-D-glucal (2a) initiated by BEt 3 /air.

Recently, phosphinoyl radicals were added to tri-O-acetyl-D-glucal (2a) by a similar mechanism. The radicals were generated from diphenylphosphine oxide and manganese(II) acetate and air, affording the 2-deoxy-2-phosphorus analogue 23 in high yield and stereoselectivity (Scheme 11). The authors could extend this reaction to various other endo-glycals 2 as well [55]. 


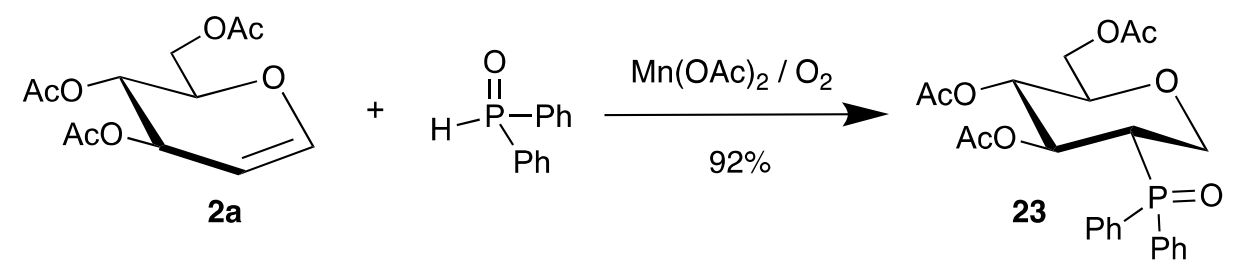

Scheme 11. Addition of diphenylphosphine oxide to tri-O-acetyl-D-glucal (2a) in the presence of manganese(II) acetate and air.

However, all methods have the disadvantage that the 1-position is reduced under the reaction conditions. Therefore, we investigated the addition of dimethyl phosphite to various benzyl-protected glycals 2e in the presence of cerium(Iv) ammonium nitrate (CAN) (Scheme 11) [56]. Now, the C-1 radical is further oxidized to a carbenium ion (see Scheme 6), which is trapped by the solvent methanol, generating the anomeric center of carbohydrates. The yields of the 2-deoxy-2-phosphorus analogues 24 are good, but stereoisomers had to be separated. Subsequent Horner-Emmons reaction with benzaldehyde afforded unsaturated carbohydrates 25 as E/Z isomers in only one step (Scheme 12) [56].

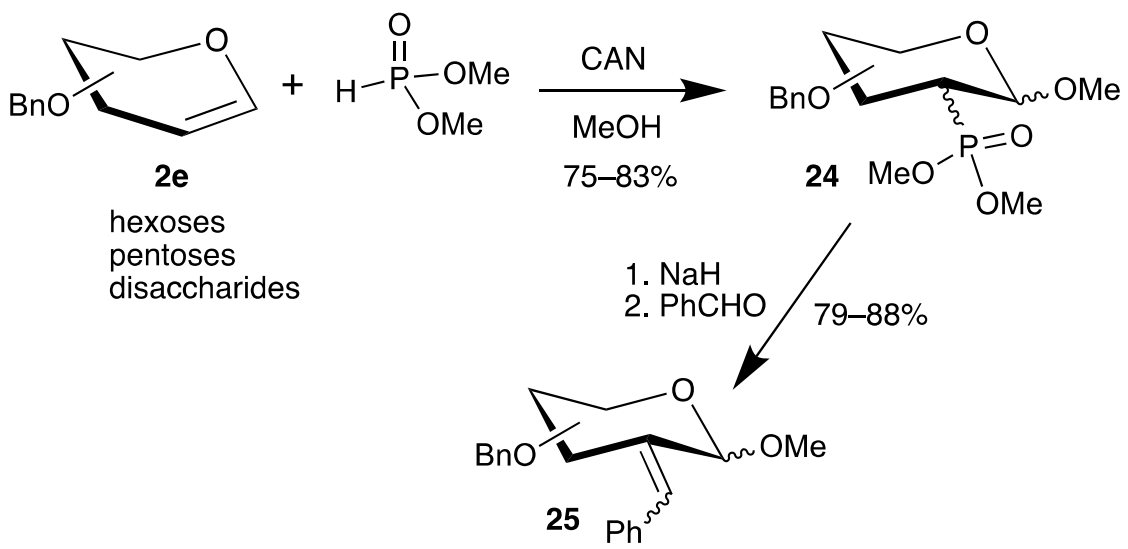

Scheme 12. Addition of dimethyl phosphite to benzyl-protected glycals $2 \mathbf{e}$ in the presence of CAN and subsequent Horner-Emmons reaction.

\section{Addition of Sulfur-Centered Radicals}

Sulfur-centered radicals can be easily generated from thiols by chemical or photochemical processes, because the S-H bond is much weaker than the corresponding O-H bond [28]. Subsequent addition to alkenes can initiate efficient chain reactions by hydrogen atom abstraction (thiol-ene reaction) or polymerizations. Indeed, the application of thiyl radicals in organic synthesis [52,57] or polymer chemistry [58] has been reviewed extensively. Even thio sugars are suitable radical precursors, and have been used for cyclizations and additions to other unsaturated carbohydrates at various positions $[59,60]$ Therefore, this mini-review will focus only on the additions of sulfur-centered radicals to endo-glycals.

The first example of a C-S bond formation by radical addition to glycals was published in 1970 [61]. Thus, the chain-reaction was initiated by cumene hydroperoxide (CHP) with thioacetic acid as radical precursor. The 2-thiocarbohydrates $\mathbf{2 6}$ were isolated in high yields with the manno isomer $\mathbf{2 6 a}$ as main product (Scheme 13). 


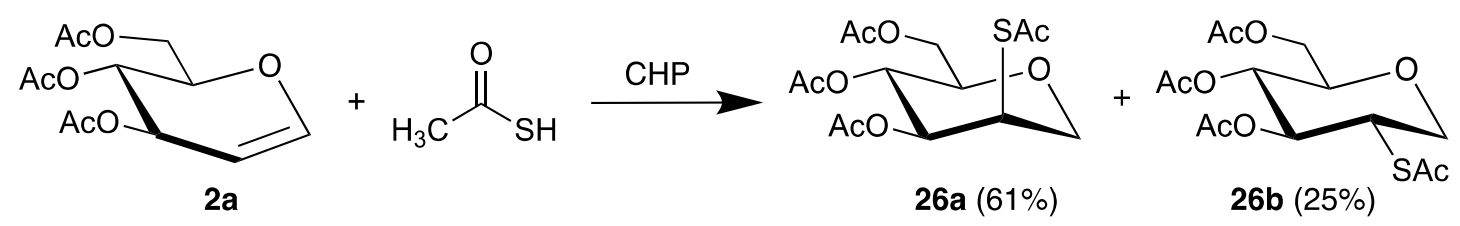

Scheme 13. Addition of thioacetic acid to tri-O-acetyl-D-glucal (2a), initiated by CHP.

The addition of alkyl thiols to tri-O-acetyl-D-glucal (2a) was realized by photochemical initiation with acetone as sensitizer [62]. The 2-S analogues $27 \mathbf{a}$ and $\mathbf{2 7 b}$ were isolated in even higher yields but with lower stereoselectivities (Scheme 14).

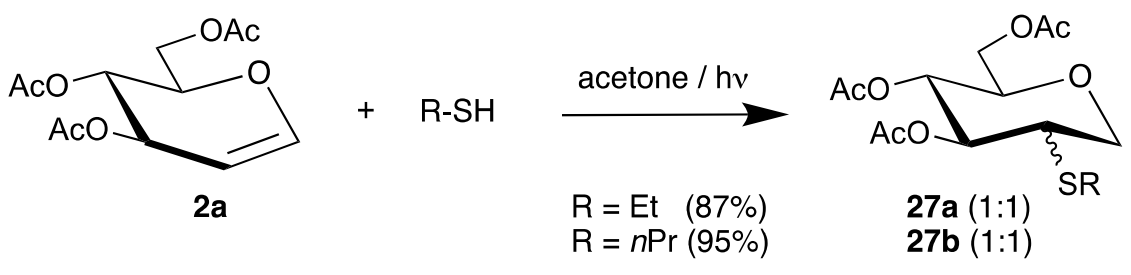

Scheme 14. Photochemical addition of alkyl thiols to tri-O-acetyl-D-glucal (2a).

More recently, 2,2-dimethoxy-2-phenylacetophenone (DPAP 28) became more attractive as radical initiator, which was developed for polymerizations and fragments under UV irradiation by an interesting mechanism (Scheme 15) [58]. Thus, in the first step a carbon-carbon bond is cleaved to generate a benzoyl radical 29, which can abstract hydrogen atoms from thiols to initiate the chain reaction. The second dimethoxybenzyl radical $\mathbf{3 0}$ can fragment into benzoate $\mathbf{3 1}$ and methyl radicals 32, which act as initiators as well.

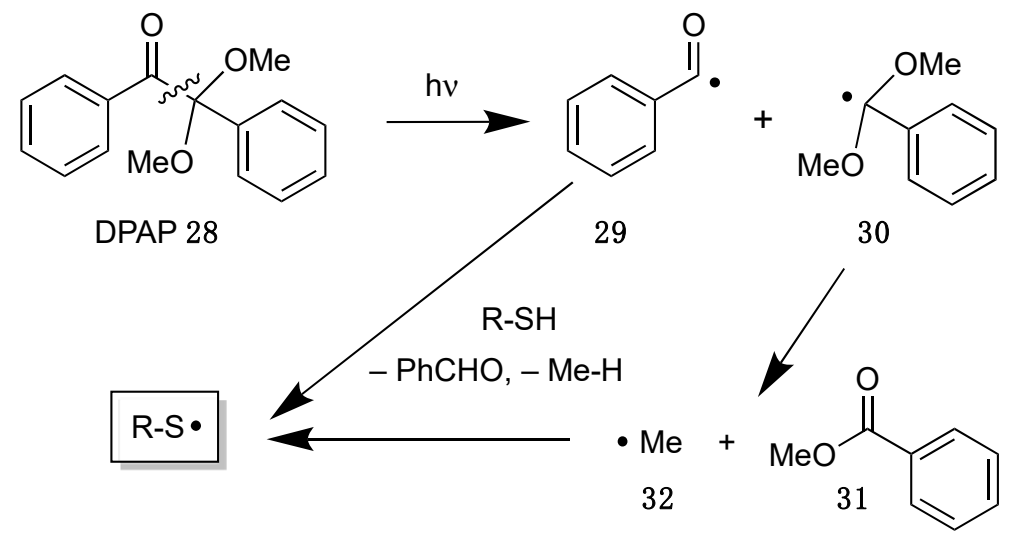

Scheme 15. Mechanism of the decomposition of 2,2-dimethoxy-2-phenylacetophenone (DPAP 28).

Dondoni applied this initiator for the synthesis of $S$-disaccharides 33 [63]. Starting from thiosugar 34 and tri-O-acetyl-D-glucal (2a), the products 33 were isolated in high yield as a 1:1 mixture of epimers (Scheme 16).

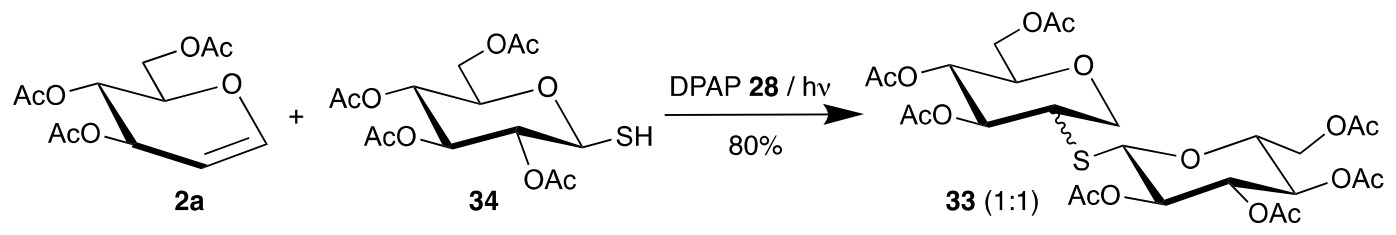

Scheme 16. Addition of thiosugar 34 to tri-O-acetyl-D-glucal (2a), initiated by DPAP 28. 
In all reactions described above (Schemes 13-16), the C-S bond is formed selectively at the 2-position of the carbohydrates, due to the enol structure of the glycals. To obtain this bond at the 1-position of sugars, another strategy was developed by Borbas [64,65]. Thus, 2-acetoxy-3,4,6-tri-O-acetyl-D-glucal (2f) was used as radical acceptor, which reacted with various thiols in the presence of DPAP. Because of the additional oxygen substituent in the 2-position, orbital interactions allow the attack of electrophilic radicals from the 1- and 2-position. However, steric interactions result in the sole formation of 1-thiosugars 35 (Scheme 17, only one example with thiosugar 34 is shown).

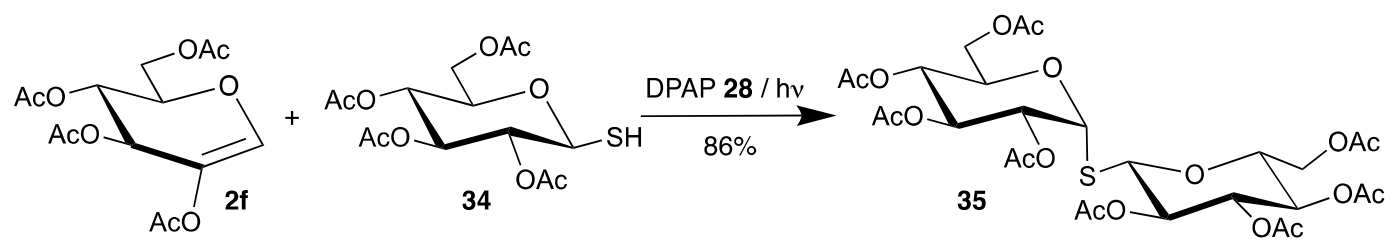

Scheme 17. Addition of thiosugar 34 to 2-acetoxy-3,4,6- tri-O-acetyl-D-glucal (2f).

The addition of thiols by radical chain reactions to the 2-position of glycals has only one disadvantage: that the 1-position is reduced under the reaction conditions. Therefore, we investigated the oxidation of ammonium thiocyanate by cerium(Iv) ammonium nitrate (CAN) and addition of the generated sulfur-centered radicals to various benzyl-protected glycals 2e (Scheme 18) [66]. Similarly to the reaction of dimethyl phosphite (Scheme 12), the C-1 radical is further oxidized to a carbenium ion, which is trapped by the solvent methanol, generating the anomeric center of carbohydrates. The yields of the 2-deoxy-2-sulfur analogues $\mathbf{3 6}$ are moderate to good, but stereoisomers have to be separated. The thiocyanate groups can be cleaved to the corresponding thiols, which can bind to concanavalin A [66] or gold nanoparticles [67].

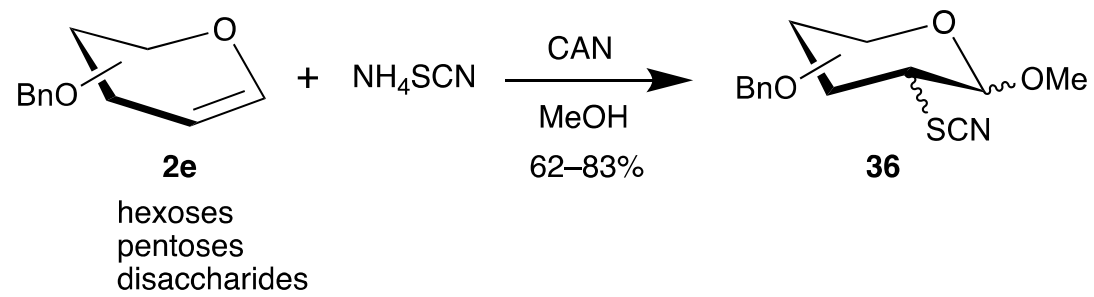

Scheme 18. Addition of thiocyanate to benzyl-protected glycals $2 \mathbf{e}$ in the presence of CAN.

\section{Summary and Perspectives}

The addition of heteroatom radicals to glycals has been known for more than 50 years and has found various applications. The aim of this mini-review was to highlight early examples and discuss recent developments. Heteroatom radicals can be easily generated by initiators, photochemical processes, or by electron transfer. They exhibit electrophilic character and add regioselectively to the 2-position of the electron-rich double bond of endo-glycals. On the other hand, they are prone to $\mathrm{H}$ atom abstraction, which limits, especially for alkoxyl radicals, their applications in carbohydrate chemistry. The simple reaction of unsaturated sugars with halogens is possible, but proceeds mainly by ionic pathways. Nitrogen-centered radicals can be generated by oxidation of azides with cerium(Iv) ammonium nitrate and add readily to glycals, which is still the best method to synthesize glycosamines. Phosphorus-centered radicals have been less intensively studied in carbohydrate chemistry, but addition products can be used for further transformations. On the other hand, the addition of sulfur-centered radicals to glycals has become very attractive for the synthesis of thio-disaccharides [68-72]. Photochemical initiators based on ketones have been developed for thiol-ene-reactions with unsaturated sugars, affording products in high yields. Finally, simple 2-thio sugars were synthesized by oxidation of thiocyanate and addition to glycals. 
In conclusion, many methods for the introduction of heteroatoms in the 2-position of carbohydrates by radical processes exist in the literature. However, the addition to endo-glycals has been limited to nitrogen-, phosphorus-, or sulfur-centered radicals until now. Therefore, there is still space for new developments for other heteroatom additions, like boryl radicals, which can be easily generated [73-75], or future applications of such radical reactions in carbohydrate chemistry.

Funding: We acknowledge the support of the Open Access Publishing Fund of the University of Potsdam.

Conflicts of Interest: The author declares no conflict of interest.

\section{References and Notes}

1. Fehér, J.; Csomós, G.; Vereckei, A. Free Radical Reactions in Medicine; Springer Science \& Business Media: Heidelberg, Germany, 1987.

2. Nicolaou, K.C.; Dai, W.-M. Chemistry and Biology of the Enediyne Anticancer Antibiotics. Angew. Chem. Int. Ed. 1991, 30, 1387-1416. [CrossRef]

3. Joshi, M.C.; Rawat, D.S. Recent Developments in Enediyne Chemistry. Chem. Biodivers. 2012, 9, 459-498. [CrossRef] [PubMed]

4. Romeo, R.; Glofre, S.V.; Chiacchio, M.A. Synthesis and Biological Activity of Unnatural Enediynes. Curr. Med. Chem. 2017, 24, 3433-3484. [CrossRef] [PubMed]

5. Early book: von Sonntag, C. Radiation Chemistry of Carbohydrates and of the Sugar Moiety in DNA; Elsevier Scientific: Amsterdam, The Netherlands, 1979.

6. Von Sonntag, C. Weiss Lecture: Carbohydrate Radicals: From Ethylene Glycol to DNA Strand Breakage. Int. J. Radiat. Biol. 1984, 46, 507-519. [CrossRef]

7. Very recent book: Chadwick, K.H. Understanding Radiation Biology; CRC Press: Boca Raton, FL, USA, 2019. [CrossRef]

8. Giese, B.B.; Be, X.; Burger, J.; Kesselheim, C.; Senn, M.; Schayer, T. The Mechanism of Anaerobic, Radical-Induced DNA Strand Scission. Angew. Chem. Int. Ed. 1993, 2, 1742-1743. [CrossRef]

9. Giese, B. Hole Injection and Hole Transfer through DNA: The Hopping Mechanism BT - Long-Range Charge Transfer in DNA I; Schuster, G.B., Ed.; Springer Berlin Heidelberg: Berlin/Heidelberg, Germany, 2004; pp. 27-44. [CrossRef]

10. First example: Giese, B.; Dupuis, J. Diastereoselective Syntheses of C-Glycopyranosides. Angew. Chem. Int. $E d .1983,22,622-623$. [CrossRef]

11. Giese, B. The Stereoselectivity of Intermolecular Free Radical Reactions. Angew. Chem. Int. Ed. 1989, 8, 969-1146. [CrossRef]

12. Giese, B.; Dupuis, J.; Gröninger, K.; Haßkerl, T.; Nix, M.; Witzel, T. Orbital Effects in Carbohydrate Radicals. In Substituent Effects in Radical Chemistry; Viehe, H.G., Janousek, Z., Merényi, R., Eds.; Springer Netherlands: Dordrecht, The Netherlands, 1986; pp. 283-296. [CrossRef]

13. Giese, B. Syntheses with Radicals-C-C Bond Formation via Organotin and Organomercury Compounds. Angew. Chem. Int. Ed. 1985, 24, 553-565. [CrossRef]

14. Giese, B. Radicals in Organic Synthesis: Formation of Carbon-carbon Bonds; Organic Chemistry Series; Pergamon Press: Oxford, UK, 1986.

15. Giese, B. Stereoselective Syntheses with Carbohydrate Radicals. Pure Appl. Chem. 1988, 60, 1655-1658. [CrossRef]

16. Hansen, S.G.; Skrydstrup, T. Modification of Amino Acids, Peptides, and Carbohydrates through Radical Chemistry. In Radicals in Synthesis II; Gansäuer, A., Ed.; Springer Berlin Heidelberg: Berlin/Heidelberg, Germnay, 2006; pp. 135-162. [CrossRef]

17. Pérez-Martín, I.; Suárez, E. Radicals and Carbohydrates. In Encyclopedia of Radicals in Chemistry, Biology and Materials; American Cancer Society: Chichester, UK, 2012. [CrossRef]

18. Very recent book: Binkley, R.W.; Binkley, E.R. Radical Reactions of Carbohydrates. 2019. Available online: http://www.carborad.com (accessed on 20 February 2020).

19. Giese, B.; Gröninger, K.S.; Witzel, T.; Korth, H.-G.; Sustmann, R. Synthesis of 2-Deoxy Sugars. Angew. Chem. Int. Ed. 1987, 26, 233-234. [CrossRef] 
20. Giese, B. Formation of CC Bonds by Addition of Free Radicals to Alkenes. Angew. Chemie Int. Ed. 1983, 22, 753-764. [CrossRef]

21. Praly, J.-P. Structure of Anomeric Glycosyl Radicals and Their Transformations under Reductive Conditions. In Advances in Carbohydrate Chemistry and Biochemistry; Academic Press: London, UK, 2000; Volume 56, pp. 65-151. [CrossRef]

22. Very recent review: De Vleeschouwer, F.; Van Speybroeck, V.; Waroquier, M.; Geerlings, P.; De Proft, F. Electrophilicity and Nucleophilicity Index for Radicals. Org. Lett. 2007, 9, 2720-2724. [CrossRef]

23. Kinfe, H.H. Versatility of Glycals in Synthetic Organic Chemistry: Coupling Reactions, Diversity Oriented Synthesis and Natural Product Synthesis. Org. Biomol. Chem. 2019, 17, 4153-4182. [CrossRef] [PubMed]

24. First example: Linker, T.; Hartmann, K.; Sommermann, T.; Scheutzow, D.; Ruckdeschel, E. Transition-Metal-Mediated Radical Reactions as an Easy Route to 2-C-Analogues of Carbohydrates. Angew. Chem. Int. Ed. 1996, 35, 1730-1732. [CrossRef]

25. Linker, T.; Sommermann, T.; Kahlenberg, F. The Addition of Malonates to Glycals: A General and Convenient Method for the Synthesis of 2-C-Branched Carbohydrates. J. Am. Chem. Soc. 1997, 119, 9377-9384. [CrossRef]

26. Review: Elamparuthi, E.; Kim, B.G.; Yin, J.; Maurer, M.; Linker, T. Cerium(IV)-Mediated C-C Bond Formations in Carbohydrate Chemistry. Tetrahedron 2008, 64, 11925-11937. [CrossRef]

27. Vankar, Y.D.; Linker, T. Recent Developments in the Synthesis of 2-C-Branched and 1,2-Annulated Carbohydrates. Eur. J. Org. Chem. 2015, 2015, 7633-7642. [CrossRef]

28. Taniguchi, T. Recent Advances in Reactions of Heteroatom-Centered Radicals. Synthesis 2017, 49, 3511-3534. [CrossRef]

29. Very recent example: Wu, X.; Zhu, C. Recent Advances in Alkoxy Radical-Promoted C-C and C-H Bond Functionalization Starting from Free Alcohols. Chem. Commun. 2019, 55, 9747-9756. [CrossRef]

30. De Armas, P.; Francisco, C.G.; Suárez, E. Reagents with Hypervalent Iodine: Formation of Convenient Chiral Synthetic Intermediates by Fragmentation of Carbohydrate Anomeric Alkoxy Radicals. Angew. Chem. Int. Ed. 1992, 31, 772-774. [CrossRef]

31. Hernández-Guerra, D.; Rodríguez, M.S.; Suárez, E. Fragmentation of Carbohydrate Anomeric Alkoxyl Radicals: Synthesis of Chiral Polyhydroxylated $\beta$-Iodo- and Alkenylorganophosphorus(V) Compounds. Eur. J. Org. Chem. 2014, 2014, 5033-5055. [CrossRef]

32. Lemieux, R.U.; Fraser-Reid, B. The Mechanisms of the Halogenations and Halogenomethoxylations of D-Glucal Triacetate, D-Galactal Triacetate, and 3,4-Dihydropyran. Can. J. Chem. 1965, 43, 1460-1475. [CrossRef]

33. Hassner, A. Regiospecific and Stereospecific Introduction of Azide Functions into Organic Molecules. Acc. Chem. Res. 1971, 4, 9-16. [CrossRef]

34. Bovin, N.V.; Zurabyan, S.É.; Khorlin, A.Y. Addition of Halogenoazides to Glycals. Carbohydr. Res. 1981, 98, 25-35. [CrossRef]

35. Rawal, G.K.; Kumar, A.; Tawar, U.; Vankar, Y.D. New Method for Chloroamidation of Olefins. Application in the Synthesis of N-Glycopeptides and Anticancer Agents. Org. Lett. 2007, 9, 5171-5174. [CrossRef]

36. Kirschning, A.; Jesberger, M.; Schönberger, A. The First Polymer-Assisted Solution-Phase Synthesis of Deoxyglycosides. Org. Lett. 2001, 3, 3623-3626. [CrossRef]

37. Islam, M.; Tirukoti, N.D.; Nandi, S.; Hotha, S. Hypervalent Iodine Mediated Synthesis of C-2 Deoxy Glycosides and Amino Acid Glycoconjugates. J. Org. Chem. 2014, 79, 4470-4476. [CrossRef]

38. Kundoor, G.; Rao, D.S.; Kashyap, S. Regioselective Direct Difunctionalization of Glycals: Convenient Access to 2-Deoxyglycoconjugates Mediated by Tetra-n-Butylammonium Iodide/Sodium Periodate. Asian J. Org. Chem. 2016, 5, 264-270. [CrossRef]

39. Nair, V.; Deepthi, A. Cerium(IV) Ammonium Nitrate-A Versatile Single-Electron Oxidant. Chem. Rev. 2007, 107, 1862-1891. [CrossRef]

40. Linker, T.; Schanzenbach, D.; Elamparuthi, E.; Sommermann, T.; Fudickar, W.; Gyóllai, V.; Somsák, L.; Demuth, W.; Schmittel, M. Remarkable Oxidation Stability of Glycals: Excellent Substrates for Cerium(IV)-Mediated Radical Reactions. J. Am. Chem. Soc. 2008, 130, 16003-16010. [CrossRef]

41. Ratcliffe, R.M.; Lemieux, R.U. The Azidonitration of Tri-O-Acetyl-D-Galactal. Can. J. Chem. 1979, 57, 1244-1251. 
42. Paulsen, H.; Lorentzen, J.P.; Kutschker, W. Erprobte Synthese von 2-Azido-2-Desoxy-D-Mannose Und 2-Azido-2-Desoxy-D-Mannuronsäure Als Baustein Zum Aufbau von Bakterien-Polysaccharid-Sequenzen. Carbohydr. Res. 1985, 136, 153-176. [CrossRef]

43. Kinzy, W.; Schmidt, R.R. Glycosylimidate, 16. Synthese Des Trisaccharids Aus Der "Repeating Unit" Des Kapselpolysaccharids von Neisseria Meningitidis (Serogruppe L). Liebigs Ann. Chem. 1985, 1985, 1537-1545. [CrossRef]

44. Keith, D.J.; Townsend, S.D. Total Synthesis of the Congested, Bisphosphorylated Morganella Morganii Zwitterionic Trisaccharide Repeating Unit. J. Am. Chem. Soc. 2019, 141, 12939-12945. [CrossRef]

45. Singh, Y.; Wang, T.; Demchenko, A.V. Direct Glycosidation of 2-Azido-2-Deoxyglycosyl Nitrates. Eur. J. Org. Chem. 2019, 2019, 6413-6416. [CrossRef]

46. Czernecki, S.; Randriamandimby, D. Azido-Phenylselenylation of Protected Glycals. Tetrahedron Lett. 1993, 34, 7915-7916. [CrossRef]

47. Santoyo-González, F.; Calvo-Flores, F.G.; García-Mendoza, P.; Hernández-Mateo, F.; Isac-García, J.; Robles-Díaz, R. Synthesis of Phenyl 2-Azido-2-Deoxy-1-Selenoglycosides from Glycals. J. Org. Chem. 1993, 58, 6122-6125. [CrossRef]

48. Jiaang, W.T.; Chang, M.Y.; Tseng, P.H.; Chen, S.T. A Concise Synthesis of the O-Glycosylated Amino Acid Building Block; Using Phenyl Selenoglycoside as a Glycosyl Donor. Tetrahedron Lett. 2000, 41, 3127-3130. [CrossRef]

49. Churchill, D.G.; Rojas, C.M. Iron(II)-Promoted Amidoglycosylation and Amidochlorination of an Allal C3-Azidoformate. Tetrahedron Lett. 2002, 43, 7225-7228. [CrossRef]

50. Lu, D.F.; Zhu, C.L.; Jia, Z.X.; Xu, H. Iron(II)-Catalyzed Intermolecular Amino-Oxygenation of Olefins through the N-O Bond Cleavage of Functionalized Hydroxylamines. J. Am. Chem. Soc. 2014, 136, 13186-13189. [CrossRef]

51. Leca, D.; Fensterbank, L.; Lacôte, E.; Malacria, M. Recent Advances in the Use of Phosphorus-Centered Radicals in Organic Chemistry. Chem. Soc. Rev. 2005, 34, 858-865. [CrossRef] [PubMed]

52. Pan, X.-Q.; Zou, J.-P.; Yi, W.-B.; Zhang, W. Recent Advances in Sulfur- and Phosphorous-Centered Radical Reactions for the Formation of S-C and P-C Bonds. Tetrahedron 2015, 71, 7481-7529. [CrossRef]

53. Kazuo, K.; Yoshida, H.; Ogata, T.; Inokawa, S. Sugars Containing a Carbon-Phosphorus Bond. I. Photochemical Addition of Diethyl Thiophosphonate to Unsaturated Sugars. Bull. Chem. Soc. Jpn. 1969, 42, 3245-3248.

54. Jessop, C.M.; Parsons, A.F.; Routledge, A.; Irvine, D.J. Phosphonyl Radical Addition to Enol Ethers. The Stereoselective Synthesis of Cyclic Ethers. Tetrahedron Lett. 2004, 45, 5095-5098. [CrossRef]

55. Zhang, F.; Wang, L.; Zhang, C.; Zhao, Y. Novel Regio- and Stereoselective Phosphonyl Radical Addition to Glycals Promoted by Mn(II)-Air: Syntheses of 1,2-Dideoxy 2-C-Diphenylphosphinylglycopyranosides. Chem. Commun. 2014, 50, 2046-2048. [CrossRef] [PubMed]

56. Elamparuthi, E.; Linker, T. Carbohydrate-2-Deoxy-2-Phosphonates: Simple Synthesis and Horner-Emmons Reaction. Angew. Chem. Int. Ed. 2009, 48, 1853-1855. [CrossRef]

57. Dénès, F.; Pichowicz, M.; Povie, G.; Renaud, P. Thiyl Radicals in Organic Synthesis. Chem. Rev. 2014, 114, 2587-2693. [CrossRef]

58. Hoyle, C.E.; Lee, T.Y.; Roper, T. Thiol-Enes: Chemistry of the Past with Promise for the Future. J. Polym. Sci. Part A Polym. Chem. 2004, 42, 5301-5338. [CrossRef]

59. Fiore, M.; Marra, A.; Dondoni, A. Photoinduced Thiol-Ene Coupling as a Click Ligation Tool for Thiodisaccharide Synthesis. J. Org. Chem. 2009, 74, 4422-4425. [CrossRef]

60. McSweeney, L.; Dénès, F.; Scanlan, E.M. Thiyl-Radical Reactions in Carbohydrate Chemistry: From Thiosugars to Glycoconjugate Synthesis. Eur. J. Org. Chem. 2016, 2016, 2080-2095. [CrossRef]

61. Igarashi, K.; Honma, T. Addition Reactions of Glycals. IV. Free-Radical Addition of Thiolacetic Acid to D-Glucal Triacetate. J. Org. Chem. 1970, 35, 606-610. [CrossRef]

62. Araki, Y.; Matsuura, K.; Ishido, Y.; Kushida, K. Synthetic Studies of Carbohydrate Derivatives with Photochemical Reaction. VII. Photochemical Addition of Ethanethiol and 1-Propanethiol to Enoses. Chem. Lett. 1973, 2, 383-386. [CrossRef]

63. Staderini, S.; Chambery, A.; Marra, A.; Dondoni, A. Free-Radical Hydrothiolation of Glycals: A Thiol-Ene-Based Synthesis of S-Disaccharides. Tetrahedron Lett. 2012, 53, 702-704. [CrossRef]

64. Lázár, L.; Csávás, M.; Herczeg, M.; Herczegh, P.; Borbás, A. Synthesis of S-Linked Glycoconjugates and S-Disaccharides by Thiol-Ene Coupling Reaction of Enoses. Org. Lett. 2012, 14, 4650-4653. [CrossRef] 
65. Lázár, L.; Csávás, M.; Hadházi, Á.; Herczeg, M.; Tóth, M.; Somsák, L.; Barna, T.; Herczegh, P.; Borbás, A. Systematic Study on Free Radical Hydrothiolation of Unsaturated Monosaccharide Derivatives with Exoand Endocyclic Double Bonds. Org. Biomol. Chem. 2013, 11, 5339-5350. [CrossRef] [PubMed]

66. Pavashe, P.; Elamparuthi, E.; Hettrich, C.; Möller, H.M.; Linker, T. Synthesis of 2-Thiocarbohydrates and Their Binding to Concanavalin A. J. Org. Chem. 2016, 81, 8595-8603. [CrossRef]

67. Fudickar, W.; Pavashe, P.; Linker, T. Thiocarbohydrates on Gold Nanoparticles: Strong Influence of Stereocenters on Binding Affinity and Interparticle Forces. Chem. Eur. J. 2017, 23, 8685-8693. [CrossRef]

68. Lázár, L.; Borbás, A.; Somsák, L. Synthesis of Thiomaltooligosaccharides by a Thio-Click Approach. Carbohydr. Res. 2018, 470, 8-12. [CrossRef]

69. Eszenyi, D.; Kelemen, V.; Balogh, F.; Bege, M.; Csávás, M.; Herczegh, P.; Borbás, A. Promotion of a Reaction by Cooling: Stereoselective 1,2-Cis- $\alpha$-Thioglycoconjugation by Thiol-Ene Coupling at $-80{ }^{\circ} \mathrm{C}$. Chem. Eur. J. 2018, 24, 4532-4536. [CrossRef]

70. Review: Dondoni, A.; Marra, A. Recent Applications of Thiol-Ene Coupling as a Click Process for Glycoconjugation. Chem. Soc. Rev. 2012, 41, 573-586. [CrossRef]

71. Lázár, L.; Juhász, L.; Batta, G.; Borbás, A.; Somsák, L. Unprecedented $\beta$-Manno Type Thiodisaccharides with a C-Glycosylic Function by Photoinitiated Hydrothiolation of 1-C-Substituted Glycals. New J. Chem. 2017, 41, 1284-1292. [CrossRef]

72. Very recent example: Kelemen, V.; Bege, M.; Eszenyi, D.; Debreczeni, N.; Bényei, A.; Stürzer, T.; Herczegh, P.; Borbás, A. Stereoselective Thioconjugation by Photoinduced Thiol-Ene Coupling Reactions of Hexo- and Pentopyranosyl D- and L-Glycals at Low-Temperature-Reactivity and Stereoselectivity Study. Chem. Eur. J. 2019, 25, 14555-14571. [CrossRef] [PubMed]

73. Ollivier, C.; Renaud, P. Organoboranes as a Source of Radicals. Chem. Rev. 2001, 101, 3415-3434. [CrossRef] [PubMed]

74. Renaud, P. Boron in Radical Chemistry. In Encyclopedia of Radicals in Chemistry, Biology and Materials; Chatgilialoglu, C., Studer, A., Eds.; Wiley: Chichester, UK, 2012. [CrossRef]

75. Taniguchi, T. Boryl Radical Addition to Multiple Bonds in Organic Synthesis. Eur. J. Org. Chem. 2019, 2019, 6308-6319. [CrossRef]

(C) 2020 by the author. Licensee MDPI, Basel, Switzerland. This article is an open access article distributed under the terms and conditions of the Creative Commons Attribution (CC BY) license (http://creativecommons.org/licenses/by/4.0/). 